\title{
Rancang Bangun Sistem Data Logger Berbasis Visual Pada Solar Cell
}

\author{
I Putu Gede Mahendra Sanjaya ${ }^{1}$, Cok Gede Indra Partha ${ }^{2}$, Duman Care Khrisne ${ }^{3}$
}

\begin{abstract}
This system developed to measurement optimizing the output of solar cell panel which using wireless systems to made a visual data logger on the solar cell which is a system to facilitate the measurement, reading, and communicating data in reading the electrical energy released in the solar cell. The design of this system has two sub-systems, the first sub-system is the design of hardware in the form of electronic device design data logger system equipped with SD card as back up data, then current sensors and voltage sensors as readers of electrical energy output in solar cell. The second sub-system is the design of software on the data logger and software design in visual basic as reading data delivery. The data reader of this system show the ampere values difference in $2.6 \%$, while the percentage difference in voltage values was 0.33 with standardization of IEC (International Electrotechnical Commission) 3.2\% ampere meter and volt meter $2,5 \%$. The system also saves the measurement results in the database and SD card data logger automatically every 15 minutes which interval in 1 minute to reading the data and the results of stored reads are date data, current values, voltage and power values.
\end{abstract}

Intisari - Untuk mengoptimalkan pengukuran keluaran dari panel solar cell maka diperlukan rancang bangun sistem nirkabel data logger berbasis visual pada solar cell yang merupakan suatu sistem untuk mempermudah pengukuran, pembacaan serta pengkomunikasian data dalam membaca energi listrik yang dikeluarkan pada solar cell. Rancang sistem ini memiliki dua buah sub sistem, sub sistem pertama adalah perancangan perangkat keras berupa perancangan perangkat elektronik sistem data logger yang dilengkapi dengan $S D$ card sebagai back up data, kemudian sensor arus dan sensor tegangan sebagai sensor pembaca keluaran energi listrik pada solar cell. Sub sistem kedua adalah perancangan perangkat lunak software pada data logger dan perancangan software pada visual basic sebagai pembacaan dalam pengiriman data. Hasil pembacaan sistem ini menunjukkan persentase perbedaan nilai arus dengan amperemeter sebesar $2.6 \%$ dan persentase perbedaan nilai tegangan dengan voltmeter sebesar $0.33 \%$ dengan standarisasi IEC (International Electrotechnical Commission) alat ukur amperemeter $\pm 3.2 \%$ dan voltmeter $\pm 2.5 \%$. Sistem ini juga menyimpan hasil pengukuran pada database dan $S D$ card data logger secara otomatis setiap 15 menit dengan interval pembacaan menimal 1 menit dan hasil pembacaan yang disimpan berupa data tanggal, nilai arus, nilai tegangan dan daya.

Kata Kunci: Solar Cell, Data Logger, Software, Database

${ }^{I}$ Mahasiswa Teknik Elektro dan Komputer Fakultas Teknik Universitas Udayana, Kampus Bukit Jimbaran. Badung Bali.80361, Tel.0361703315 fax.703315; email: putu.mahen5@gmail.com

${ }^{2,3}$ Dosen Teknik Elektro dan Komputer Fakultas Teknik Universitas Udayana, Kampus Bukit Jimbaran, Badung Bali.80361, Tel.0361703315 fax.0361703315: email: cokindra@unud.ac.id, duman@unud.ac.id

\section{PENDAHULUAN}

Solar cell merupakan sebuah perangkat yang dapat menghasilkan energi listrik secara langsung dari pancaran cahaya matahari. Mengingat Indonesia berada pada garis khatulistiwa dengan pancaran cahaya matahari yang cukup banyak sepanjang tahun, sehingga menjadi sumber energi yang sangat baik untuk dikembangkan. Pemanfaatan energi matahari dalam pembangkitan energi listrik telah banyak dilakukan dengan menggunakan panel sel surya, salah satunya adalah penelitian perbandingan unjuk kerja antara panel sel surya berpenjejak dengan panel sel surya diam. Namun dalam penelitian ini masih dilakukakannya pengukuran secara manual, seperti mengukur energi listrik yang dihasilkan solar cell dengan mengukur ke lokasi penempatan dari solar cell dan masih perlunya pengukuran lain seperti mengukur nilai tegangan dan daya yang dihasilkan dari solar cell [1].

Untuk memaksimalkan kinerja dari pengukuran maka diperlukan sebuah sistem nirkabel data logger berbasis visual pada solar cell, yang memuat data mengenai pengukuran, pembacaan dan pengkomunikasian data dalam membaca keluaran energi listrik pada solar cell. Sistem ini menggunakan sistem nirkabel, dimana merupakan sebuah sistem yang dikomunikasikan dengan media komputer menggunakan gelombang radio sebagai media komunikasi dalam membaca dan mengirim data keluaran dari solar cell.

Rancang sistem ini, menggunakan dua buah sub sistem yakni sub sistem data logger, dimana sistem data logger ini digunakan sebagai sensor pembacaan dan pengiriman data dari objek yang diukur serta dilengkapi dengan media penyimpanan $S D$ card yang bertujuan untuk back up data apabila terjadi kerusakan pada komputer. Kemudian sub sistem software, dimana merupakan sebuah sistem untuk mengontrol, membaca, memproses, dan menyimpan data hasil pengukuran dari data logger dengan kecepatan pembacaan minimal 1 menit yang bertujuan untuk mengurangi terjadinya loss data ketika penyimpanaan data pada database. Data hasil pembacaan tersebut kemudian divualiasikan dalam bentuk grafik pada sistem software untuk informasi tambahan mengenai kondisi solar cell.

\section{TINJAUAN PUSTAKA}

\section{A. Solar Cel}

Solar Cell merupakan sebuah pembangkit listrik yang menggunakan cahaya matahari untuk mengkonversikan radiasi sinar foton matahari menjadi energi listrik melalui sel surya (fotovoltaik). Sel surya merupakan sebuah lapisanlapisan tipis yang terbuat dari bahan semikonduktor silikon ( $\mathrm{Si}$ ) murni yang tersusun menjadi modul surya. Solar cell umumnya terdiri dari beberapa komponen utama yakni, generator sel surya (PV generator) yang merupakan susunan modul surya pada suatu sistem penyangga, inverter untuk mengkonversi arus DC menjadi arus AC kemudian baterai 
dengan sistem penyimpanan serta sistem kontrol dan monitoring operasi solar cell, [2].

\section{B. Data Logger}

Data logger merupakan sebuah perangkat elektronik yang digunakan untuk mengumpulkan dan merekam data dari objek yang direkam baik secara terintegrasi dengan sensor eksternal maupun sensor internal seperti sensor arus dan sensor tegangan. Data real time yang direkam dan dikumpulkan kemudian disimpan secara MMC/SD card untuk back up data apabila terjadi kerusakan pada data logger [3].

Data logger atau logging data yang digunakan dalam perancangan sistem ini adalah berbasis mikrokontroller yang berfungsi sebagai kontrol dari sistem yang terintegrasi dengan perangkat masukan digital dan analog [3].

\section{Mikrokontroller}

Mikrokontroler yang dipakai pada penelitian ini adalah mikrokontroller ATmega328 dimana, Mikrokontroler tersebut dikonversi menjadi modul Arduino ATMega328 melalui proses burn bootloader untuk proses pengoprasian pembacaan pada data logger. Burn bootloader merupakan sebuah proses pemasukan program pengoperasian pada mikrokontroler, sehingga dapat berfungsi sebagai modul Arduino ATMega328 dalam membaca objek yang diukur [4].

\section{Memori}

Memori merupakan sebuah media yang merujuk pada media penyimpanan data, memori yang dapat digunakan pada data logger yakni [5]:

1. RAM (Random Access Memory) digunakan untuk penyimpanan pada saat bekerja yakni pada saat pembacaan dari saluran masukan data logger.

2. EEPROM (Electrically Erasable \& Programmable Read Only Memory) digunakan untuk menyimpan sistem pengoperasian pada mikroprosesor maupun menyimpan data. EEPROM dapat diprogram, dibaca (data yang tersimpan) dan dihapus melalui port serial PC.

\section{E. Radio Telemetry}

Radio Telemetry RCTimer dimana sistem dasarnya menggunakan 3DR Radio System dan 100 persen kompatibel dalam membantu dan mempermudah kinerja data logger dalam pengiriman data. Berikut spesifikasi radio telemetry [6]:

1. Frekwensi $433 \mathrm{Mhz}$

2. Sensitifitas penerima sampai $-121 \mathrm{dBm}$

3. Kekuatan pengiriman sampai $20 \mathrm{dBm}(100 \mathrm{~mW})$

4. Data rate di udara sampai 250kbps

5. Frequency hopping spread spectrum (FHSS)

6. Adaptive time division multiplexing (TDM)

7. Open source firmware

\section{F. Sensor Arus ACS712 20A}

ACS712 merupakan suatu IC terpaket yang mana berguna untuk membantu kinerja dari data logger dalam pembacaan nilai arus. Sensor arus ACS712 20A menggantikan trafo arus yang relatif besar dalam hal ukuran. Pada prinsipnya ACS712 sama dengan sensor efek xvii hall lainnya yaitu dengan I Putu Gede Mahendra Sanjaya: Rancang Bangun Sistem... memanfaatkan medan magnetik di sekitar arus kemudian dikonversi menjadi tegangan yang linier dengan perubahan arus. [7].

\section{G. Sensor Tegangan (Voltage Divider)}

Sensor tegangan dalam mengambil sinyal tegangan AC dari plant yang ada, untuk dapat dibaca oleh data logger maka sinyal tegangan AC tersebut harus di cuplik dan di searahkan kemudian di masukkan ke ADC internal mikrokontroller. Rangkaian sensor tegangan, menggunakan prinsip pembagi tegangan (voltage divider) [8].

\section{H. Microsoft Visual Basic}

Microsoft visual basic (Visual Basic), adalah sebuah perangkat lunak yang digunakan untuk membuat suatu aplikasi berbasis dekstop. Pada Microsoft Visual Basic mempunyai tampilan grafis dan lingkungan IDE (Intergrated Development Environment) yang sangat berbeda dari sebelumnnya sehingga mempurmudah dalam pembuatan tampilan visual berbasis dekstop [9].

\section{KAJIAN PUSTAKA}

\section{A. Metode Penelitian}

Penelitian ini dilakukan di Jurusan Teknik Elektro, Fakultas Teknik Universitas Udayana pada tanggal 1 Desember 2016 sampai 31 Desember 2016. Sebelum dimulainya penelitian, diperlukan pengumpulan data-data yang berhubungan dengan system data logger nirkabel berbasis visual pada solar cell untuk perancangan skema perangkat keras (data logger) dan perangkat lunak (software). Kemudian dilakukan pengukuran pada solar cell menggunakan data logger yang telah terhubung pada software untuk memperoleh nilai arus, tegangan, dan daya.

Pengoperasian data logger yang telah terhubung dengan software memiliki 3 proses yakni proses pengiriman data dari data logger menuju software, kemudian penyimpanan pada data logger dan software, dan penampilan data pengukuran pada data base software. Berikut adalah diagram alur dari langah penelitian pada gambar 1 .

Adapun langkah-langkah perancangan yang dilakukan adalah sebagai berikut:

1. Pengumpulan data dan spesifikasi komponen yang berhubungan dengan rancang bangun sistem nirkabel data logger berbasis visual pada solar cell.

2. Perancangan algoritma komunikasi dan penyimpanan data pada data logger dan software.

3. Perancangan disain dan pembuatan software visualisasi menggunakan visual basic.

4. Pengujian pengukuran arus, daya, dan tegangan pada solar cell menggunakan data logger dan pengiriman data menuju software.

5. Uji coba sistem data logger berbasis visual pada solar cell.

6. Apabila pengujian keseluruhan sistem apabila sudah berjalan dengan baik maka proses sudah selesai.

\section{B. Gambaran Umum}

Dalam rancang bangun sistem nirkabel data logger berbasis visual pada solar cell ini terdiri dari dua buah bagian

$$
\text { p-ISSN:1693 - 2951; e-ISSN: 2503-2372 }
$$


sistem yaitu sistem data logger dan sistem software dapat dilihat pada gambar 2 .

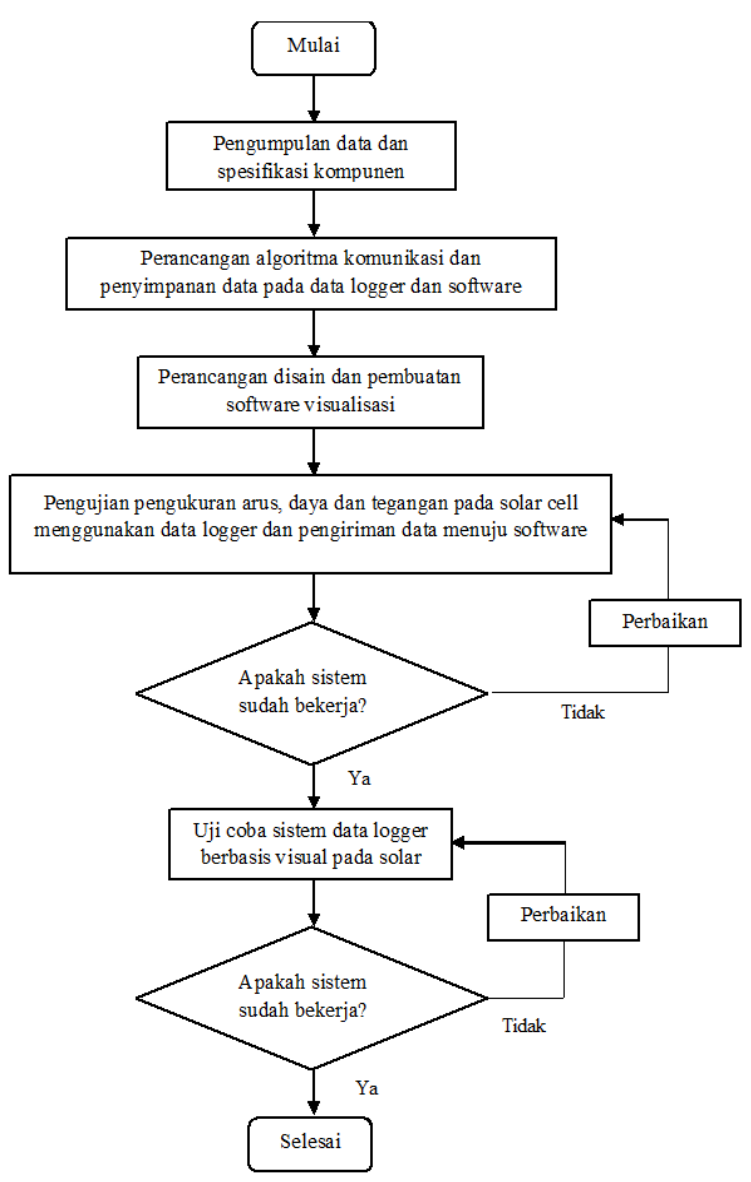

Gambar 1: Diagram alur dari langah penelitian

Dari gambar 2 dapat dijelaskan bahwa mekanisme pemrosesan data pertama kali yakni pengkalibrasian waktu antara data logger dengan software. Apabila pengkalibrasian waktu telah sesuai, operator kemudian ditugaskan untuk memilih serial port untuk menghubungkan koneksi antara data logger dengan software, dan menekan tombol connect untuk memulai proses menjalankan pengukuran pada data logger. Data hasil pengukuran tersebut kemudian disimpan kedalam $S D$ card dan dikirim terus menerus menuju software melalui komunikasi radio telemetri, sehingga data dapat diproses dan dipisahkan sesuai dengan keperluan. Data yang telah sesuai, secara otomatis tersimpan pada database software dan ditampil dalam bentuk grafik secara terus menerus selama pengukuran berlangsung.

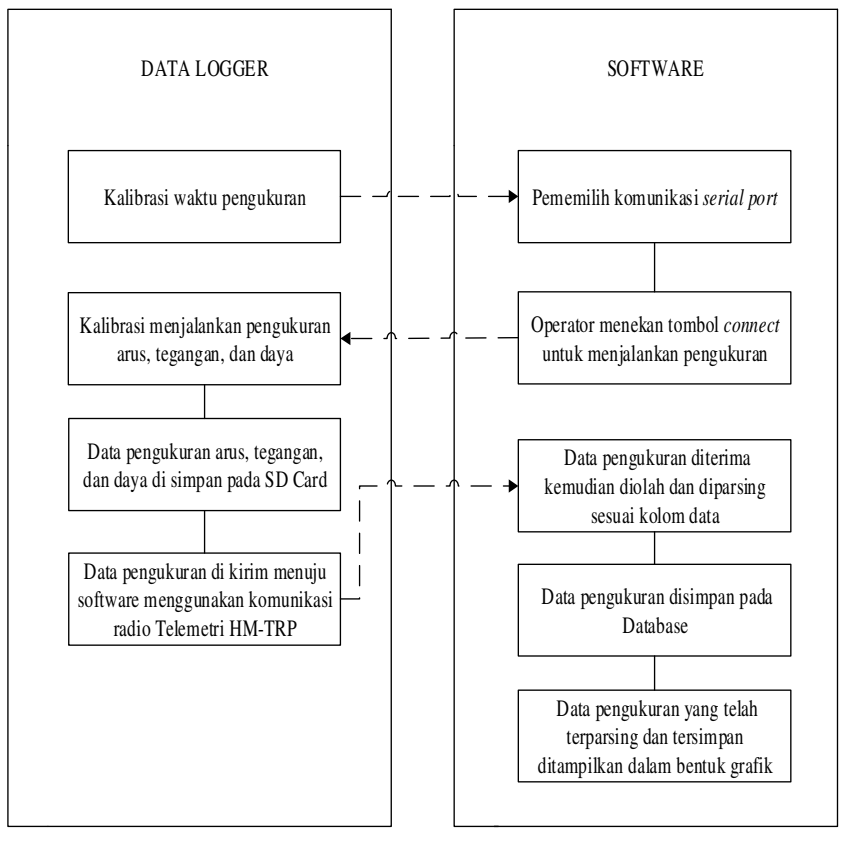

Gambar 2: Gambaran umum

C. Diagram Alir Sistem Data Logger Menggunakan Software Arduino IDE

Diagram alir sistem data logger menggunakan software Arduino IDE pada gambar 3.

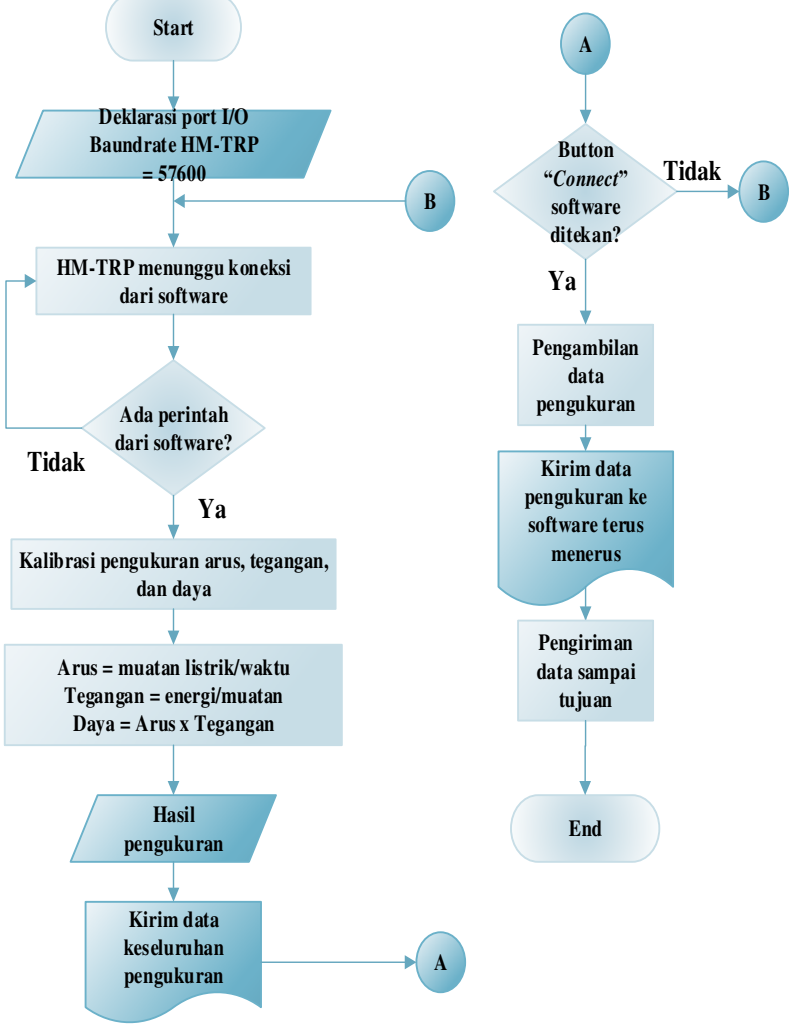

Gambar 3: Diagram alir sistem data logger menggunakan software Arduino IDE

I Putu Gede Mahendra Sanjaya: Rancang Bagung Sistem.. 
Dari gambar 3 dapat dijelaskan bahwa proses pertama kali dimulai dari pendeklarasian port input, output, baudrate dari masing-masing Tx Rx yang digunakan pada data logger, dengan tujuan mempermudah proses pengiriman dan penerimaan data dalam pengukuran. Apabila proses inisialisasi telah sesuai, maka data logger mulai menunggu perintah dari software untuk menjalankan pengukuran pada data logger dan pengiriman data menuju software dengan menggunakan sinyal radio telemetri. Pada software, operator hanya menekan tombol "connect" untuk proses menjalankan pengukuran dan pengambilan data secara terus menerus yang dikirm dari data logger menuju software.

\section{Diagram Alir Sistem Software Menggunakan Visual Basic}

Berikut ini merupakan diagram alir software menggunakan visual basic pada gambar 4 .

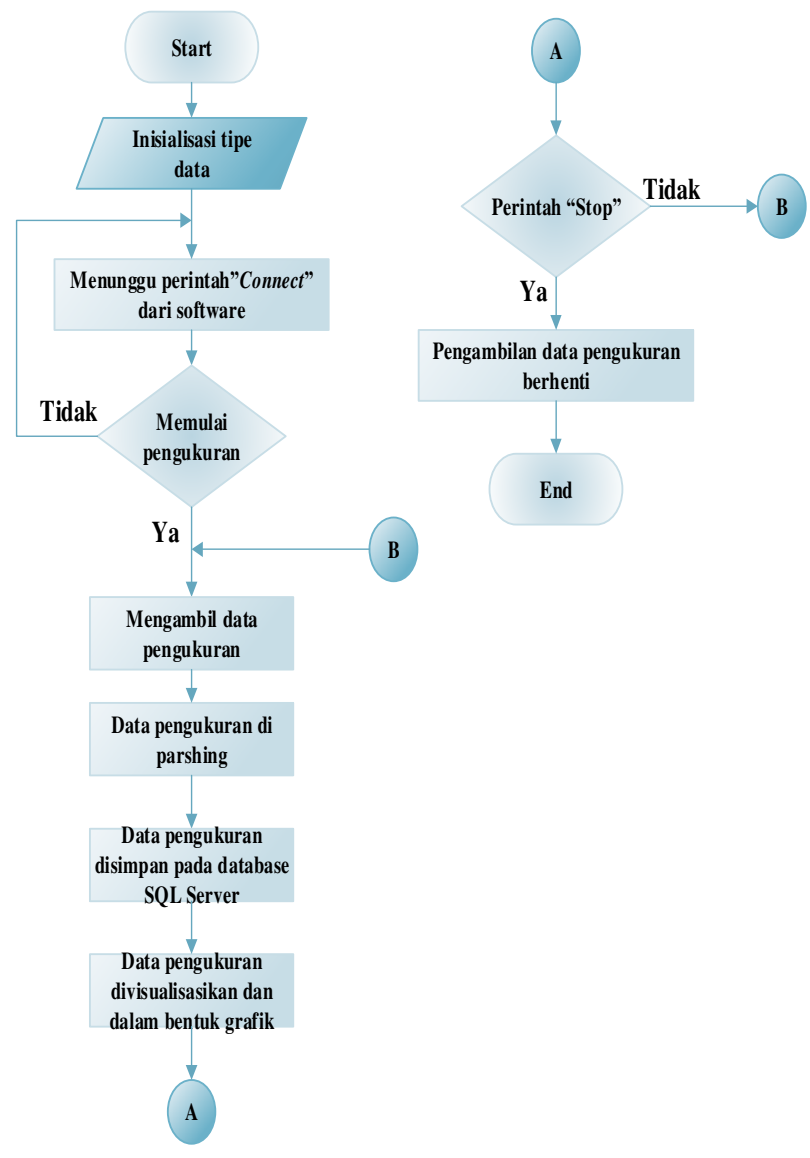

Gambar 4: Diagram alir sistem software menggunakan visual basic

Dari gambar 4 dapat dijelaskan bahwa proses pertama kali dimulai dari proses penginisialisasi data apakah data sudah sesuai dengan data yang diinginkan. Kemudian operator ditugaskan menekan tombol "connect", untuk memulai proses pengukuran dan pengambilan data pengukuran pada data logger serta data yang masuk kemudian dipisahkan sesuai dengan kolom yang telah ditentukan pada software. Data yang telah sesuai dengan keperluan secara otomatis tersimpan dalam database SQL Server sehingga hasil dari data tersebut I Putu Gede Mahendra Sanjaya: Rancang Bangun Sistem... dapat langsung divisualisasikan dalam bentuk grafik. Kemudian apabila ada perintah stop dari operator, software berhenti melakukan pengukuran dan pengambilan data pada data logger.

\section{E. Perancangan Database}

Database merupakan sekumpulan data yang sudah tersusun dan saling berelasi sehingga cepat dan mudah dalam pengolahanya sesuai dengan kebutuhan. Dalam database ini terdapat idData sebagai primary key, Waktu sebagai DateTime, Tegangan, Arus, dan Daya sebagai Float yang digunakan untuk penyimpanan data hasil dari pengukuran.

\section{HASIL DAN PEMBAHASAN}

\section{A. Realisasi Perancangan Perangkat Keras dan Perangkat Lunak}

Realisasi perancangan perangkat keras dan perangkat lunak sistem nirkabel data logger berbasis visual pada solar cell dapat dilihat pada gambar 5 dan gambar 6.

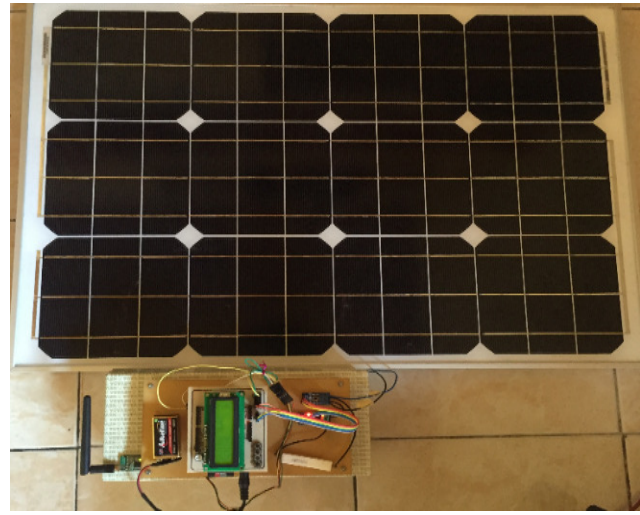

Gambar 5: Realisasi hasil perancangan perangkat keras pada solar cell

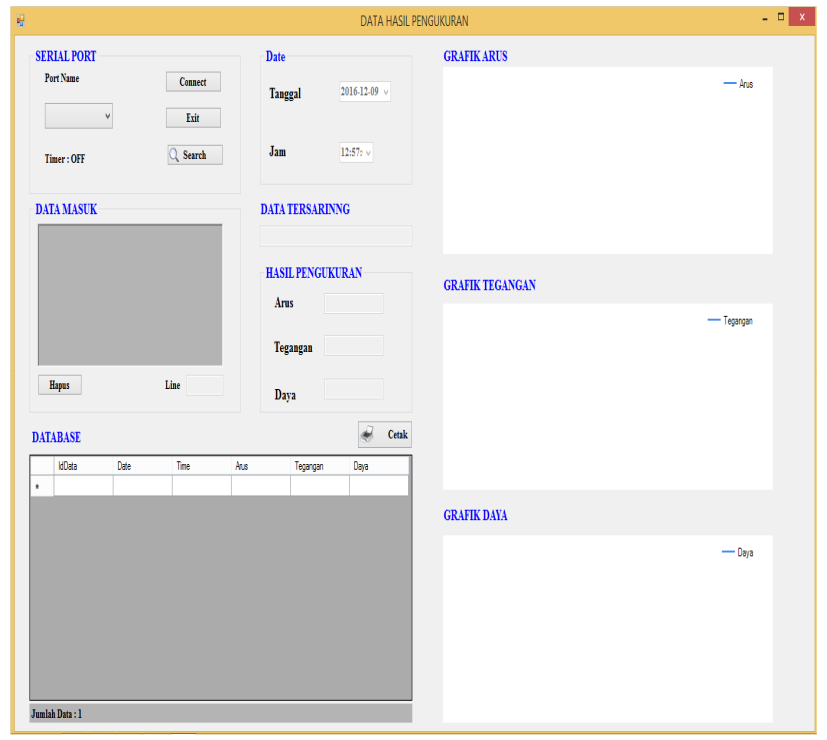

Gambar 6: Realisasi hasil perancangan perangkat lunak

p-ISSN:1693 - 2951; e-ISSN: 2503-2372 
Dari perancangan perangkat keras dan perangkat lunak dapat dijelaskan bahwa pengukuran dan pembacaan sudah dapat berkerja dengan optimal. Sehingga nilai yang didapatkan sudah sesuai dengan pengukuran secara manual.

\section{B. Pengujian Komunikasi Antara Data Logger Dengan Komputer}

Pengujian ini bertujuan untuk mengetahui jarak maksimal pengkomunikasian antara data logger dengan komputer. Sehingga dapat mengurangi terjadinya loss communication pada saat pengiriman dan penerimaan data. Dalam pengujian komunikasi tersebut nilai yang dikirimkan secara otomatis terikirim menuju komputer dan ditampilkan secara terus menerus pada serial monitor Arduino IDE dengan menggunakan komunikasi radio telemetry. Berikut adalah hasil pengujian komunikasi anatara data logger dengan komputer pada tabel 1 .

TABEL I

PENGUJIAN KOMUNIKASI DATA LOGGER DENGAN KOMPUTER

\begin{tabular}{|c|c|c|c|}
\hline No & Jarak & Keterangan & Status \\
\hline 1 & 5 Meter & $\begin{array}{l}\text { Outdoor, Line of sight, Tidak } \\
\text { berawan }\end{array}$ & Terhubung \\
\hline 2 & 15 Meter & $\begin{array}{l}\text { Outdoor, Line of sight, Tidak } \\
\text { berawan }\end{array}$ & Terhubung \\
\hline 3 & 30 Meter & $\begin{array}{l}\text { Outdoor, Line of sight, Tidak } \\
\text { berawan }\end{array}$ & Terhubung \\
\hline 4 & 50 Meter & $\begin{array}{l}\text { Outdoor, Line of sight, Tidak } \\
\text { berawan }\end{array}$ & Terhubung \\
\hline 4 & 50 Meter & $\begin{array}{l}\text { Outdoor, Line of sight, } \\
\text { Berawan }\end{array}$ & Terhubung \\
\hline 5 & 75 Meter & $\begin{array}{l}\text { Outdoor, Line of sight, Tidak } \\
\text { berawan }\end{array}$ & Terhubung \\
\hline 6 & 75 Meter & $\begin{array}{l}\text { Outdoor, Line of sight, } \\
\text { Berawan }\end{array}$ & Terhubung \\
\hline 7 & 100 Meter & $\begin{array}{l}\text { Outdoor, Line of sight, Tidak } \\
\text { Berawan }\end{array}$ & Terhubung \\
\hline 8 & 100 Meter & $\begin{array}{l}\text { Outdoor, Line of sight, } \\
\text { Berawan }\end{array}$ & Terhubung \\
\hline 9 & 50 Meter & $\begin{array}{l}\text { Outdoor, } \quad \text { Terhalang } \\
\text { Bangunan, Tidak berawan }\end{array}$ & $\begin{array}{l}\text { Putus } \\
\text { Nyambung }\end{array}$ \\
\hline 10 & 50 Meter & $\begin{array}{l}\text { Outdoor, Terhalang } \\
\text { Bangunan, Berawan }\end{array}$ & $\begin{array}{l}\text { Putus } \\
\text { Nyambung }\end{array}$ \\
\hline
\end{tabular}

Hasil pengujian komunikasi antara data logger dengan Komputer dapat dihasilkan bahwa dalam pengkomunikasian pengiriman data yang berjarak 5 meter sampai 100 meter diluar ruangan dalam kondisi line of sight, berawan ataupun tidak berawan hasil yang didapatkan koneksi tidak mengalami gangguan. Kemudian apabila jarak 5 meter sampai 100 meter diluar ruangan terhalangi oleh bangunan dalam kondisi berawan ataupun tidak berawan koneksi yang terjadi adalah putus nyambung.

\section{Pengujian Sensor Arus}

Pengujian ini bertujuan untuk mengetahui seberapa besar dan akurat pengukuran yang dilakukan pada objek yang diukur menggunakan sensor arus yang terpasang pada data logger. Dalam pengujiannya sonsor arus menggunakan mikrokontroller ATMega328 untuk memproses pembacaan nilai analog dari hasil pengukuran pada objek yang diukur. Berikut adalah hasil pengujian sensor arus pada tabel 2 .

TABEL II

HASIL PENGUJIAN SENSOR ARUS DENGAN AMPEREMETER

\begin{tabular}{|c|c|c|c|c|c|}
\hline \multirow{2}{*}{ No } & \multirow{3}{*}{ Beban } & \multirow{3}{*}{ Sumber } & \multicolumn{3}{|c|}{ Hasil Pengukuran } \\
\cline { 4 - 6 } & & & $\begin{array}{c}\text { Amperemeter } \\
(\mathbf{A})\end{array}$ & $\begin{array}{r}\text { Sensor } \\
\text { Arus } \\
(\mathbf{A})\end{array}$ & $\begin{array}{c}\text { Persentase } \\
\text { Perbedaan }\end{array}$ \\
\hline 1 & $10 \mathrm{Ohm}$ & 5 Volt & 0,41 & 0,42 & $2,4 \%$ \\
\hline 2 & $10 \mathrm{Ohm}$ & 7 Volt & 0,66 & 0,67 & $1,5 \%$ \\
\hline 3 & $10 \mathrm{Ohm}$ & 9 Volt & 0,87 & 0,89 & $2,3 \%$ \\
\hline 4 & $10 \mathrm{Ohm}$ & 12 Volt & 1,15 & 1,18 & $2,6 \%$ \\
\hline 5 & $10 \mathrm{Ohm}$ & 18 Volt & 1,76 & 1,79 & $1,7 \%$ \\
\hline
\end{tabular}

Dari perhitungan persentase perbedaan sensor arus dengan amperemeter didapatkan hasil persentase perbedaan amperemeter dengan sensor arus tertinggi sebesar $2.6 \%$ dengan standar nilai pengukuran voltmeter IEC (International Electrotechnical Commission) sebesar $\pm 3.2 \%$ ), sehingga nilai hasil pengukuran mengunakan sistem ini masih dalam rentan nilai toleransi alat ukur.

\section{Pengujian Sensor Tegangan}

Pengujian ini bertujuan untuk mengetahui seberapa besar dan akurat pengukuran yang dilakukan pada objek yang diukur menggunakan sensor tegangan yang terpasang pada data logger. Dalam pengujiannya sonsor tegangan menggunakan mikrokontroller ATMega328 untuk memproses pembacaan nilai analog dari hasil pengukuran pada objek yang diukur. Berikut adalah hasil pengujian sensor tegangan pada tabel 3.

TABEL III

HASIL PENGUJIAN SENSOR TEGANGAN DENGAN VOLTMETER

\begin{tabular}{|c|l|c|c|c|}
\hline \multirow{2}{*}{ No } & \multirow{2}{*}{ Sumber } & \multicolumn{3}{|c|}{ Hasil Pengukuran } \\
\cline { 3 - 5 } & & Voltmeter & $\begin{array}{c}\text { Sensor } \\
\text { Tegangan }\end{array}$ & $\begin{array}{c}\text { Persentase } \\
\text { Perbedaan }\end{array}$ \\
\hline 1 & Regulator 5 Volt & 4,89 & 4,9 & $0,2 \%$ \\
\hline 2 & Regulator 12 Volt & 11,75 & 11,77 & $0,33 \%$ \\
\hline 3 & Beterai 18 Volt & 17,89 & 17,92 & $0,33 \%$ \\
\hline 4 & Beterai 9 Volt & 8,94 & 8,97 & $0,33 \%$ \\
\hline 5 & Baterai 3,4 Volt & 3,35 & 3,36 & $0,33 \%$ \\
\hline
\end{tabular}

Dari perhitungan persentase perbedaan sensor tegangan dengan voltmeter didapatkan hasilkan persentase perbedaan 
voltmeter dengan sensor tegangan tertinggi sebesar $0.33 \%$ dengan nilai standar IEC (International Electrotechnical Commission) pengukuran voltmeter sebesar $\pm 2.5 \%)$, sehingga nilai hasil pengukuran mengunakan sistem ini masih dalam rentan nilai toleransi alat ukur.

\section{E. Pengujian Penyimpanan Pada SD Card Data Logger}

Dari pengujian ini, $S D$ Card digunakan sebagai media penyimpanan data hasil pengukuran pada solar cell dan menggunakannya untuk back up data apabila terjadi kerusakan pada prangkat komputer. Dalam pengujiannya data logger yang telah dilengkapi dengan data logger shield secara otomatis tersimpan dalam SD Card. Berikut adalah hasil dari penyimpanan data pada $S D$ card dapat dilihat pada gambar 7 .

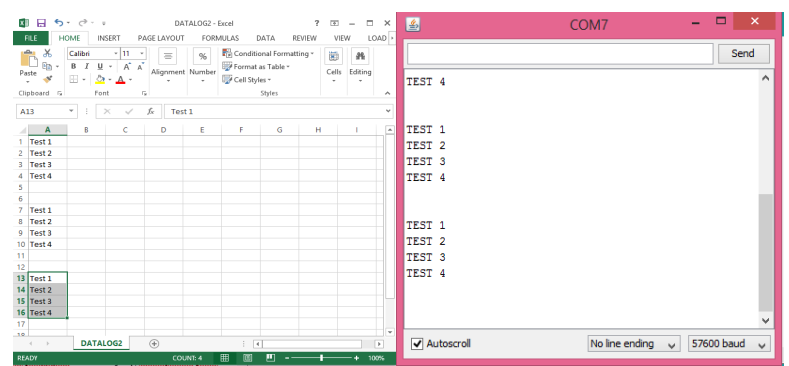

Gambar 7: Hasil penyimpanan data pada SD card data logger dan SD card yang ditampilan pada Microsoft Excel

\section{F. Pengujian RTC (Real Time Clock) Pada Data Logger}

Pengujian ini bertujuan untuk memberikan inputan waktu pada data logger sesuai dengan keadaan waktu nyata. Dalam pengujiannya RTC menggunakan mikrokontroller ATMega328 sebagai media penghubung antara RTC dengan LCD sehingga dapat ditampilkan waktu sesuai dengan waktu nyata. Berikut adalah dari hasil dari pengujian RTC pada gambar 8 .

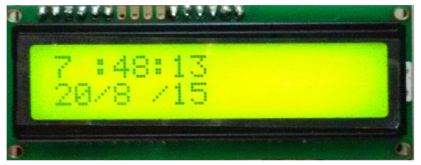

Gambar 8: Hasil Pengujian RTC

\section{G. Pengujian Penyimpanan dan Menampilkan Data Pengukuran pada Database}

Pada pengujian ini bertujuan untuk mengetahui apakah proses penyimpanan dan menampilakan data sudah sesuai dengan kolom-kolom yang telah ditentukan dan tidak adanya loss data pada saat proses penyimpanan data pada database. Berikut adalah proses pengujian penyimpanan data pada gambar 9.

Garis merah pada gambar 9, menjelaskan bahwa penyimpanan sudah berjalan dengan baik dan sudah sesuai dengan keperluan, serta dapat ditampilkan pencarian data yang tersimpan pada database berdasarkan tanggal ataupun jam yang diinginkan. Tampulan pencarian data pengukuran dapat dilihat pada gambar 10 .
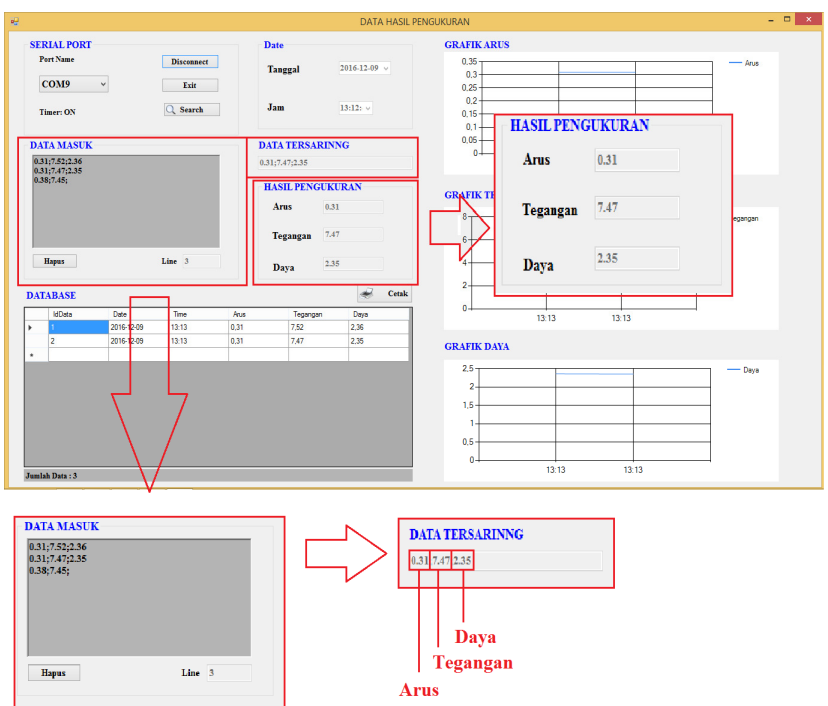

Gambar 9: Hasil pengujian penyimpanan data pada database

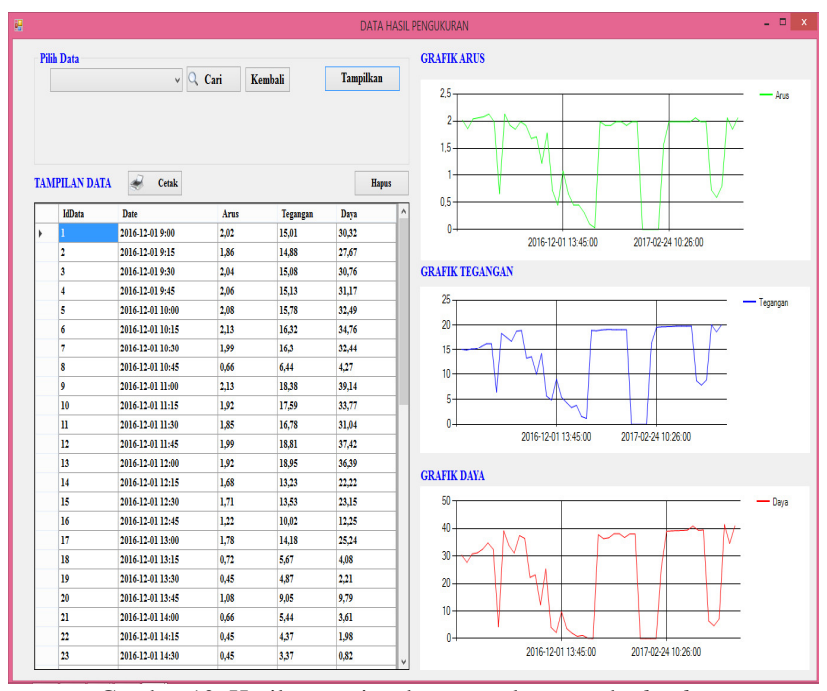

Gambar 10: Hasil pencarian data pengukuran pada database

\section{H. Pengujian Keseluruhan Sistem Nirkabel Data Logger Berbasis Visual Pada Solar Cell}

Pengujian keseluruhan sistem ini dilakukan untuk mengetahui keakuratan dalam melakukan pengukuran pada solar cell menggunakan data logger yang telah dilengkapi dengan sensor arus dan sensor tegangan, sehingga data hasil pengukuran sesuai dengan yang ditampilkan pada software. Berikut adalah tahap pengujian keseluruhan sistem pada gambar 11 dan gambar 12. 


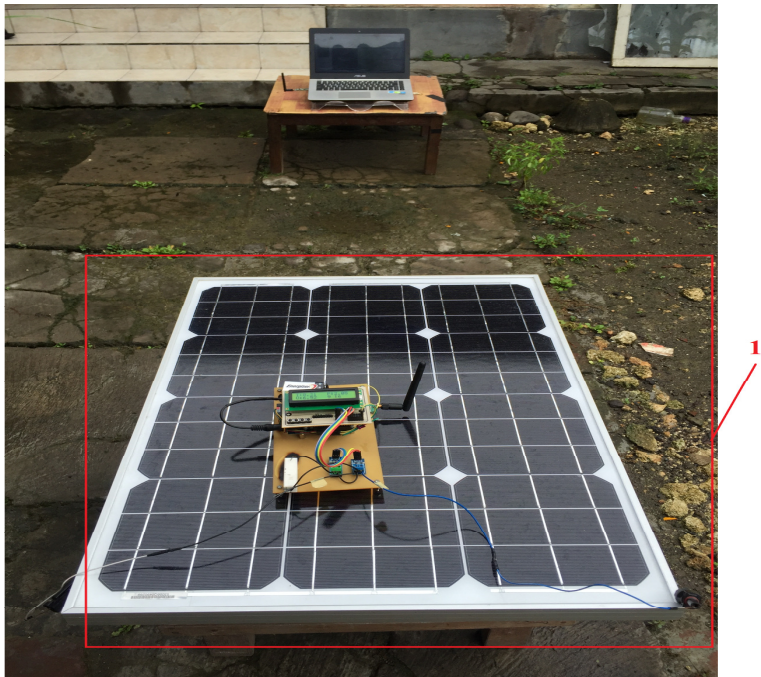

Gambar 11: Pengujian data logger yang telah terpasang pada solar cell dan memulai pengukuran

Garis merah pada gambar 11 dan 12 menandakan bahwa tahap pengujian sistem pengukuran dan pembacaan sudah berjalan dengan sangat baik dan sesuai dengan keperluan yang diinginkan, sehingga data yang dihasilkan dapat diproses lebih lanjut dalam mengoptimalkan pengukuran pada solar cell. Berikut adalah tabel hasil pengukuran pada solar cell pada tanggal 1 Desember 2016 pukul 9.00 sampai dengan 15.15 WITA.

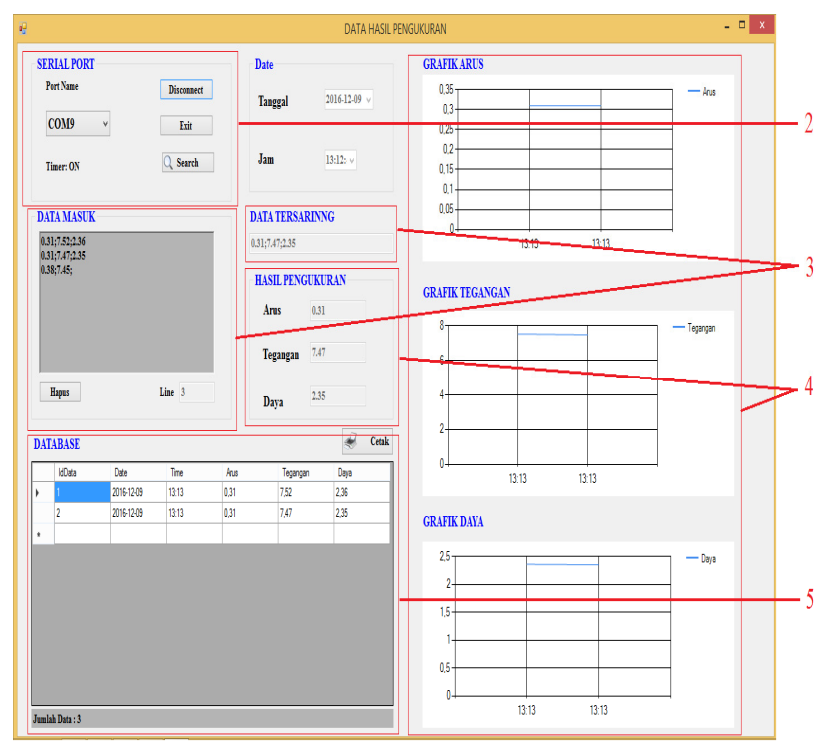

Gambar 12: Pengujian software yang sudah terkoneksi dengan data logger dan memulai proses pengukuran

TABEL IV

DATA HASIL PENGUKURAN SOLAR CELL TANGGAL 1 DESEMBER 2016

\begin{tabular}{|c|c|c|c|c|}
\hline Tanggal & Jam & Arus (I) & Tegangan (V) & Daya (P) \\
\hline 2016-12-01 & $09: 00: 00$ & 2.02 & 15.01 & 30.32 \\
\hline 2016-12-01 & $09: 15: 00$ & 1.86 & 14.88 & 27.67 \\
\hline 2016-12-01 & $09: 30: 00$ & 2.04 & 15.08 & 30.76 \\
\hline
\end{tabular}

\begin{tabular}{|l|l|l|l|l|}
\hline 2016-12-01 & $09: 45: 00$ & 2.06 & 15.13 & 31.17 \\
\hline 2016-12-01 & $10: 00: 00$ & 2.08 & 15.78 & 32.49 \\
\hline $2016-12-01$ & $10: 15: 00$ & 2.13 & 16.32 & 34.76 \\
\hline $2016-12-01$ & $10: 30: 00$ & 1.99 & 16.30 & 32.44 \\
\hline $2016-12-01$ & $10: 45: 00$ & 0.66 & 6.44 & 4.27 \\
\hline $2016-12-01$ & $11: 00: 00$ & 2.13 & 18.38 & 39.14 \\
\hline 2016-12-01 & $11: 15: 00$ & 1.92 & 17.59 & 33.77 \\
\hline 2016-12-01 & $11: 30: 00$ & 1.85 & 16.78 & 31.04 \\
\hline $2016-12-01$ & $11: 45: 00$ & 1.99 & 18.81 & 37.42 \\
\hline $2016-12-01$ & $12: 00: 00$ & 1.92 & 18.95 & 36.39 \\
\hline $2016-12-01$ & $12: 15: 00$ & 1.68 & 13.23 & 22.22 \\
\hline $2016-12-01$ & $12: 30: 00$ & 1.71 & 13.53 & 23.15 \\
\hline $2016-12-01$ & $12: 45: 00$ & 1.22 & 10.02 & 12.25 \\
\hline $2016-12-01$ & $13: 00: 00$ & 1.78 & 14.18 & 25.24 \\
\hline $2016-12-01$ & $13: 15: 00$ & 0.72 & 5.67 & 4.08 \\
\hline $2016-12-01$ & $13: 30: 00$ & 0.45 & 4.87 & 2.21 \\
\hline $2016-12-01$ & $13: 45: 00$ & 1.08 & 9.05 & 9.79 \\
\hline $2016-12-01$ & $14: 00: 00$ & 0.66 & 5.44 & 3.61 \\
\hline $2016-12-01$ & $14: 15: 00$ & 0.45 & 4.37 & 1.98 \\
\hline $2016-12-01$ & $14: 30: 00$ & 0.24 & 3.37 & 0.82 \\
\hline $2016-12-01$ & $14: 45: 00$ & 0.31 & 3.82 & 1.20 \\
\hline $2016-12-01$ & $15: 00: 00$ & 0.10 & 1.58 & 0.16 \\
\hline $01 / 12 / 2016$ & $15: 15: 00$ & 0.03 & 1.19 & 0.04 \\
\hline
\end{tabular}

GRAFIK ARUS

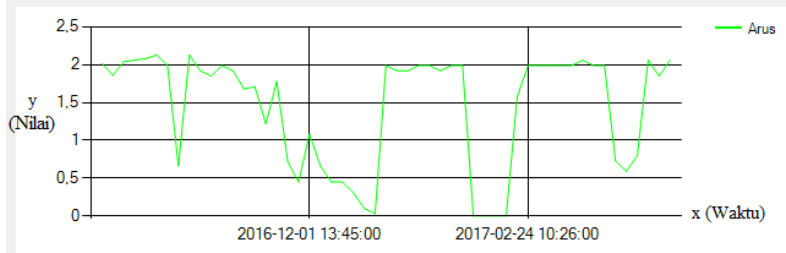

GRAFIK TEGANGAN

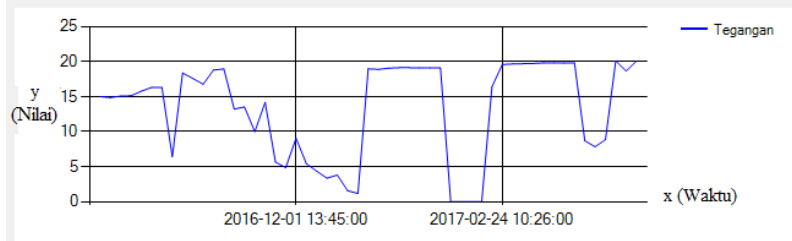

GRAFIK DAYA

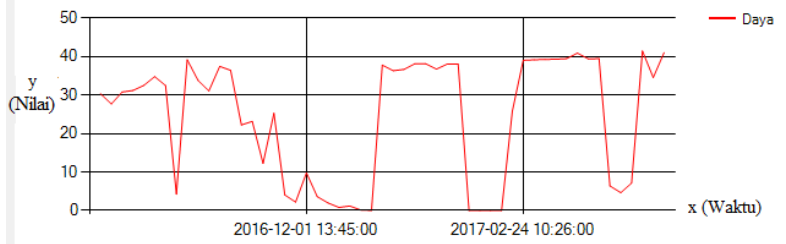

Gambar 13: Grafik pengukuran solar cell tanggal 1 Desember 2016 pada tampilan software

Dari tabel 6 dapat dijelaskan bahwa data pengukuran yang dilakukan pada tanggal 1 Desember 2016. Dimulai pukul 9.00 WITA sampai 15.15 WITA didapatkan nilai pengukuran tertinggi pada pukul 11.00 WITA. Dimana nilai arus tertinggi 
sebesar 2.13 Volt, tegangan tertinggi 18.38 Amper dan daya Tertinggi 39.18 Watt. Berdasarkan hasil pengukuran diatas maka dapat disimpulkan waktu yang baik dalam menghasilkan energy listrik yakni dari pukul 09.00 sampai 13.00 dan dapat dibuat grafik hasil pengukuran arus, tegangan dan daya yang dihasilkan solar cell. Berikut adalah grafik hasil pengukuran pada gambar 13

\section{Kesimpulan}

Simpulan yang dapat diambil berdasarkan hasil dari pengujian dan pembahasan yang telah dilakukan adalah sebagai berikut:

1. Dengan didapatnya nilai arus dan tegangan pada pembacaan dan pengukuran Sistem Nirkabel Data Logger Berbasis Visual Pada Solar Cell didapatkan juga nilai daya dengan mengkalikan nilai arus dan nilai tegangan yang dihasilakan.

2. Data hasil pembacaan dan pengukuran Sistem Nirkabel Data Logger Berbasis Visual Pada Solar Cell dapat dihasilkan data yang tersimpan pada database software dan SD Card data logger setiap 15 menit sekali (minimal 1 menit), sehingga data yang disimpan dan ditampilkan dapat terpantau hanya dengan melihat pada software yang telah terkoneksi dengan data logger yang terpasang pada solar cell

3. Persentase nilai pengukuran arus Sistem Nirkabel Data Logger Berbasis Visual Pada Solar Cell dengan amperemeter tertinggi sebesar $2,6 \%$ dan nilai tengangan dengan voltmeter tertinggi sebesar $0,33 \%$ dimana nilai standar IEC (International Electrotechnical Commission) pengukuran amperemeter sebesar $\pm 3.2 \%$ dan voltmeter sebesar $\pm 2.5 \%$ ) sehingga pengukuran masih dalam rentan nilai toleransi.

\section{REFERENSI}

[1] C. Syafaruddin. "Perbandingan Unjuk Kerja Antara Panel Sel Surya Berpenjejak Dengan Panel Sel Surya Diam”. Jurnal Teknik Elektro. Vol. 9 No.1 Januari - Juni 2010. Universitas Mataram. 2010.

[2] Setiawan I.K.A. "Analisis Unjuk Kerja Pembangkit Listrik Tenaga Surya (Plts) Satu Mwp Terinterkoneksi Jaringan Di Kayubihi, Bangli”. Jurnal Teknologi Elekro. Vol 13, No 1. Universitas Udayana. 2014.

[3] Nugroho T.A. "Sistem Logging Data Menggunakan FTP Berbasis Jaringan 3G". Jurnal Telematika. Vol. 10 No. Institut Harapan Bangsa. 2015.

[4] Suardiana I.M.N. "Rancang Bangun Sistem Pembacaan Jumlah Konsumsi Air Pelanggan Pdam Berbasis Mikrokontroler Atmega328 Dilengkapi Sms”. Jurnal Teknologi Elektro. Vol 15, No 1. Universitas Udayana. 2016

[5] Hoperf. 2006. HM-TRP Series 100mW Transceiver modules V1.0. http://www.hoperf.com/upload/rf_app/HM-TRP.pdf.

[6] F. Daryanto. "Moitoring Lampu Koridor Gedung A. D4 Pens-ITS dengan Menggunakan Wirelles Sensor Network (WSN)" Institut Teknologi Sepuluh Nopember. 2007.

[7] M.Y.E. Adiptya, H. Wibawanto. "Sistem Pengamatan Suhu dan Kelembaban Pada Rumah Berbasis Mikrokontroller ATMega8". Jurnal Teknik Elektro. Vol. 5, No. 1. Januari-Juni 2013. Universitas Negeri Semarang. 2013.

[8] F.S Prabadi, H. Ananta. "PC Data Logger Berbasis Telemetri". Jurnal Kompetensi Teknik. Vol. 3, No. 1, November 2011. Universitas Semarang. 2011.

[9] Setyawan I.D.C. "Rancang Bangun Aplikasi Penyebaran Rumah Tangga Miskin Menggunakan Flash (Actionscript 2.0) Dan Visual Basic Berbasis Desktop (Studi Kasus: Kota Denpasar)". E-Jurnal Spectrum. Vol 2, No 2, 2 Juni 2015. Universitas Udayana. 2015

I Putu Gede Mahendra Sanjaya: Rancang Bangun Sistem... 